\title{
ROLE OF PAKISTAN STUDIES TEXTBOOK IN PROMOTING PATRIOTISM AT SECONDARY LEVEL
}

${ }^{1}$ Lal Muqaddar Khan, ${ }^{2}$ Dr. Umbreen Ishfaq, ${ }^{3}$ Dr. Tehseen Tahir, ${ }^{4}$ Dr. Muhammad Saeed Khan

\begin{abstract}
Textbooks are the only available teaching learning material in most schools of Pakistan. Moreover according to Mahmood (2010), in Pakistan, textbooks are used in the classrooms without knowing their usefulness. Consequently it is needed to evaluate the textbooks which we are using in our classrooms. This study aimed to analyze the role of Pakistan Studies' textbooks at secondary level published by Khyber Pakhtunkhwa Textbook Board Peshawar in promotion of patriotism. The contents of Pakistan Studies' textbooks at secondary level about patriotism were analyzed with the help of a questionnaire. All the 130 Public Sector Higher Secondary Schools \& High Schools (77 male and 53 female) and 8531 students (3732 girls and 4799 boys) of 10th class at district Haripur were considered as population of the study. Stratified random sampling technique was used to select 40 public sector high and higher secondary schools of district Haripur. From each school one teacher and ten students were obtained. Data were collected by a questionnaire from teachers and students of $10^{\text {th }}$ class. Questionnaire was developed according to the objectives of the study. Almost nine indicators for patriotism were probed. There were five responses for respondents i.e. agree, strongly agree, undecided, disagree and strongly disagree. Questionnaire was distributed among 40 Pakistan Studies teachers teaching at the schools and 400 students of $10^{\text {th }}$ class. Data collected on the basis of five point-scales were analyzed by using percentage and mean. Results of the study concluded that contents of Pakistan Studies Textbooks promoted patriotism, democratic values, human rights, freedom
\end{abstract}

\footnotetext{
${ }^{1}$ Department of Education, University of Haripur

${ }^{2}$ Assistant Professor, Department of Education, University of Haripur

${ }^{3}$ Assistant Professor, Department of Education, University of Haripur

${ }^{4}$ Assistant Professor, Department of Education, University of Haripur
} 
of thoughts, peace in society, tolerance, national development however the content lacks the contribution of national heroes and sense of responsibility and dutifulness.

Keywords: Pakistan Studies, Patriotism, Secondary Level

\section{Introduction}

Role of textbook is very important in learning process despite the fact that technological innovations enabled educators to teach in new ways and achieve new goals. For decades textbooks have been used without piloting and formal investigation for knowing their usefulness (Mahmood, $2010 \mathrm{p}$. 8). In developing countries, textbook is used as major component in the teaching learning process at school. It becomes practical manifestation of curriculum. Among many more factors, a textbook requires to meet the objectives of curriculum, students' needs, duration of the course and allocated budget, etc. (Jupri, 1994, p. 1).

Curriculum is a track or course to be followed. In educational context curriculum can be viewed as a course or plan for learning. It is an organized set of educational intentions (Khan, 2012, p. 1). It is a way to achieve the aims of education and determine the work of teacher and student. It enables the teacher to select the appropriate method of teaching. Curriculum plays an important role in transmitting the values of liberty, equality, justice, respect for dignity of the individual, and group living (Shahid, 2000). Curriculum promotes national integration. Along with spiritual and moral values in life, love for motherland, unity and respect for every faith is also developed (Rashid, 2004).

Khan (2012, p. 3), observed that curriculum provided knowledge about the rights and responsibilities of the people. National curriculum boosts national unity and patriotism (Hashmi, 2014). Curriculum of Pakistan Studies underscores the importance of national integration, cohesion and patriotism. Among others the one of its core objective, the national integration, cohesion and patriotism, is held to be attained through the teaching learning process (Ministry of Education, 2006).

\subsection{Research Objectives}

Following were the objectives of study.

1.To analyze the contents of Pakistan Studies textbooks about patriotism at secondary level by teachers' perceptions. 
2.To analyze the contents of Pakistan Studies textbooks regarding patriotism at secondary level by students' perceptions.

\section{Review of Literature}

Etymologically the term 'curriculum' comes from the Latin root which means 'race course' where the words 'race' and 'course' are suggestive of the time and the path respectively. The curriculum, therefore, can be seen as the prescribed course of study to be covered in a specific timeframe (Ministry of Education, 2006). Curriculum of social sciences has to serve some purposes. For example to develop a code based on ethical and democratic values, to solve problem faced by the society, to promote international understanding and peace, to promote scientific inquires, to appreciate scientific discoveries for human wellbeing, to develop emotional and social adjustment, to impart knowledge about family life, to use and hold the skills and habits of critical and constructive thinking (Khan, 2012. p. 2).

Curriculum is of many types such as Bloom (2006) presented three basic types of curriculum i.e. explicit, implicit and null. Explicit curriculum is a type of curriculum that is found in written form and teaching plans. Implicit or hidden curriculum is a type of curriculum which is based on how a particular theory about teaching and learning is put in practice, for instance, the importance or value of a topic is implicitly communicated by tone of voice and time spent. Null curriculum is a form or type of curriculum which is not taught deliberately under the pressure of higher authorities and society or not taught due to teacher's ignorance or lack of ability and knowledge.

Similarly, case mentioned two types of curriculum. First one is specialized contents curriculum and the second one is process curriculum. Specialized contents curriculum includes a body of facts, concepts, and principles necessary in the functioning of some specific economic role while process curriculum develop thinking skills among the students which cannot be developed in natural environment (Khan, 2012, p. 2).

Curriculum contents is considered the starting point while formulating curricula by many educationist and teachers. They believe that intuition is the source of contents selection. But only intuition is not sufficient for constructing curricula. Objectives based on predetermined goals and aims 
are important to formulate an effective curriculum. Curriculum contents are subject matter of the teaching learning process. It includes the knowledge, skills and values associated with that subject. Contents consisted on knowledge; skills and process, and values. Knowledge included truth, clarification, main beliefs and classification. Skills and process consisted of reading, writing, calculating, dancing, critical thinking, decision making, communicating. Values are the beliefs about something whether it is good or bad, right or wrong, beautiful or ugly (Print, 1993).

Textbook is described as an instruction which is helpful in teaching. Teachers and students depend on it for carrying out teaching learning activities. It is a true source of instruction and used in both type of education, formal and informal. It is produced in line with the prescribed syllabus and the major ideas of the subject matter are selected, summarized and organized in such a way that fulfill the moral and psychological requirements of the students (Faizi, 2010, p. 62). Textbooks play a vital role in teaching because of their close relation to classroom instruction. The topics of subject are presented in an organized form enabling the students to search them easily. Efforts are put forwarded to state organized classroom lessons, structured with suitable exercises and activities. Moreover, textbooks have very important position in curriculum development and are considered as the most significant tool for the implementation of a new curriculum in many countries (Valverde, et.al., 2002). Textbook evaluation is a process of obtaining the value of given material and making judgment of its effects on the learners (Tomlinson \& Masuhara, 2004). It is helpful in selection of the most suitable textbook for learners by pointing out the strengths and shortcomings of the material (Mukundan, 2007). It enables the teacher to make its teaching more effective and result orientated by highlighting the effectiveness of the given materials in the textbook. Teacher adopts well informed and useful strategies after knowing the strong points and observing the shortcomings (Sarem, Hamidi, \& Mahmoudie, 2013).

For textbook evaluation a level approach is recommended by many researchers. In this approach at first an overview i.e. impressionistic evaluation is recommended followed by in depth evaluation of textbook. 
In impressionistic evaluation a quick overview of the textbook is carried out in order to determine the outer quality general suitability of the textbook. After impressionistic evaluation the next stage is to go in depth and find inner quality of the subject matter. While conducting in depth evaluation a detailed description is made about how textbook or a portion of the textbook meets the aims and objectives and need of the learners (Lawrence, 2011 p. 11). Creation of single textbook was recommended by Commission on National Education 1959. Before her recommendation the multiple textbooks were available in the market for use in the classroom. After the recommendation of the Commission, the provincial textbook boards were established in order to solve some obstacle faced by the multiple textbooks. Commission made some allegations on multiple textbooks i.e. these textbooks are prepared by non-professional, merit is not maintained, textbooks are selected on the pressure of administration, temptation practices of the publishers, low quality presentation of the textbook, lack of evaluation, high prices, use of cram books along with textbook (Ministry of Education, 1959).

Establishment of the textbook boards resulted in the production of quality textbooks in the beginning but with the passage of time the quality of the textbooks started declining. It was felt on the part of the government that in order to create quality textbooks the policy of single textbook need considerations. Thus the National Education Policy 19982010 declared;

Quality of textbooks has been a continuous source of concern. [Single] Sole-textbooks, which are prescribed up to secondary level, are causing a number of problems in teaching, learning and evaluation of students (Ministry of Education, 1998 p.3).

To solve this problem the development and use of multiple textbooks were allowed in both private and public schools. Textbook boards and private publishers under policy provisions started to develop textbooks after the year 2000. Ministry of Education reviews and approves the submitted textbook under the guidelines provided by national curriculum. When a textbook is submitted, the Ministry of Education composes 
National Curriculum Review Committee for its review and approval (Mahmood, 2010).

Curriculum of Pakistan Studies emphasizes the importance of National Integration, cohesion and patriotism (Ministry of Education, 2006). Patriotism is the one's special affection for the country. Special affection refers one's love for the country. Thus love for one's own country is called patriotism. It is a sense of personal identification with the country. It includes special concern for the progress of the country and a force that prepares the people to scarify for the betterment of the country (Nathanson, 1989). Personal identification with country refers to the feeling of pride over country's merits and achievement and shame for its wrongs and shortcomings. Thus patriotism can be defined as one's love for his/her country, recognition with it, and apprehension for its fellow citizen's prosperity, development and progress (Primoratz, 2015).

There were researches that analyzed the subject of Pakistan Studies at different level of education. Khan (2012) has conducted research on "A Critical Analysis of Pakistan Studies Curricula". The researcher assessed the contents of Pakistan Studies in connection with its relevancy with students' needs and interests. Principles of survival and utility, vertical alignment of the contents and purpose of the society were also explored.

Another research work "The Reflection of Islamic Values in the Compulsory Subjects of Social Sciences at Secondary (IX-X) Level in Karachi" was conducted by Waqar-un-Nisa Faizi. The researcher has examined the relationship between Islamic values and course contents of Islamiyat and Pakistan Studies at secondary level.

Hashmi (2014) presented a research paper entitled "Content Analysis of the Provincial Pakistan Studies Textbook for Class IX-X" in Journal of Education and Social Sciences. In this research study the researcher has analyzed the contents of the Pakistan Studies Textbook against the objectives set by the Federal Ministry of Education by using a set framework with additional focusing on textbook printing and publishing style.

The researches that were conducted on the subject of Pakistan Studies showed the overall analysis and evaluation of Pakistan Studies Curricula and Pakistan Studies Textbooks. They did not analyze deeply the contents 
of Pakistan Studies Textbooks about patriotism. Although Khan (2012, p. 245) inquired whether the Curriculum of Pakistan Studies highlighted the importance of national integration, unity and patriotism but did not analyze the presentation of the concepts in the textbooks of Pakistan Studies. Faizi (2010, p. 170) evaluated only the reflection of Islamic values in the subject of Pakistan Studies. Research work by Hashmi (2014) on contents analysis of Provincial Pakistan Studies Textbook for Class IX-X did not analyze the contents of Pakistan Studies Textbook on patriotism.

\section{Research Methodology}

Nature of the study was descriptive. Survey research method was more suitable for the study to obtain the perceptions of students and teachers. Quantitative research design was used to obtain and analyze the data.

\subsection{Population}

All the 130 Public Sector Higher Secondary Schools \& High Schools (77 male and 53 female) and 8531 students (3732 girls and 4799 boys) of $10^{\text {th }}$ class at district Haripur were considered as population of the study.

\subsection{Sample \& Sampling Technique}

Stratified random sampling technique was used to select 40 public sector high and higher secondary schools of district Haripur. From each school one teacher (i.e. 40 teachers) and ten students (i.e. 400 students) were sampled.

\subsection{Research Instrument}

The role of the contents in promotion of patriotism was analyzed through the perceptions of Teachers and students, by using a questionnaire. Questionnaire probed nine indicators. These indicators included promotion of patriotism, democratic values, implementation of basic human rights, freedom of thoughts, importance of peace in the society, religious tolerance, opportunities for national development, information about national heroes, importance of dutifulness and sense of responsibilities. The questionnaire consisted of five point Likert scale having options; a.) Strongly Agree b.) Agree c.) Undecided, d.) Disagree and e.) Strongly Disagree.

\subsection{Data Collection}


Questionnaires were distributed among 40 Pakistan Studies Teachers teaching at secondary level to obtain the perceptions of teachers about the contents of textbooks. Moreover, to obtain the perceptions of students another questionnaire was distributed among 400 students studying at secondary level class 10 .

\section{Data Analysis \& Interpretation}

Obtained data were analyzed through descriptive statistical measures i.e. percentage and mean.

\section{Perceptions of Students and Teachers}

Perceptions of students and teachers regarding the role of Pakistan Studies Textbooks at secondary level in promoting patriotism are given in the following tables:

Table 1. Students and teachers perceptions about the promotion of patriotism

\begin{tabular}{llllllll} 
Students & $\mathrm{F}$ & 31 & 24 & 52 & 188 & 103 & \multirow{2}{*}{3.78} \\
& $\%$ & $7.8 \%$ & $6.0 \%$ & $13.1 \%$ & $47.2 \%$ & $25.9 \%$ & \\
\multirow{2}{*}{ Teachers } & $\mathrm{F}$ & 7 & 3 & 5 & 14 & 11 & 3.47 \\
& $\%$ & $17.5 \%$ & $7.5 \%$ & $12.5 \%$ & $35.0 \%$ & $27.5 \%$ & \\
\hline
\end{tabular}

This table highlighted the responses about the promotion of patriotism obtained through students and teachers perceptions, results showed the agreement of $73.1 \%$ students while disagreement of $19.1 \%$ of the students. The mean 3.78 proved that most of students were in favor of the statement. Teachers' perceptions proved that $62.5 \%$ teachers had the same opinion and $20.0 \%$ teachers differed with it. The mean 3.47 proved that mostly teachers were in favor of it.

Table 2. Perceptions of students and teachers about democratic values

\begin{tabular}{llllllll}
\hline \multirow{2}{*}{ Students } & $\mathrm{F}$ & 57 & 24 & 55 & 155 & 107 & \multirow{2}{*}{3.56} \\
& $\%$ & $14.3 \%$ & $6.0 \%$ & $13.8 \%$ & $38.9 \%$ & $26.9 \%$ & \\
\multirow{2}{*}{ Teachers } & $\mathrm{F}$ & 7 & 0 & 6 & 19 & 8 & 3.52 \\
& $\%$ & $17.5 \%$ & $0 \%$ & $15.0 \%$ & $47.5 \%$ & $20.0 \%$ & 3 \\
\hline
\end{tabular}

Results depicted in the table about the encouragement of democratic values, elaborated that $65.8 \%$ students were incompliance while $19.8 \%$ students were in noncompliance. The mean 3.56 demonstrated that the statement was supported by the students. Results obtained from teachers depicted that $67.5 \%$ teachers were incompliance while $15.0 \%$ teachers 
were in noncompliance. The mean 3.52 demonstrated that the statement was supported by the teachers.

Table 3. Perceptions of students and teachers about human rights

\begin{tabular}{llllllll}
\hline \multirow{2}{*}{ Students } & $\mathrm{F}$ & 54 & 33 & 66 & 144 & 101 & \multirow{2}{*}{3.51} \\
& $\%$ & $13.6 \%$ & $8.3 \%$ & $16.6 \%$ & $36.2 \%$ & $25.4 \%$ & \\
\multirow{2}{*}{ Teachers } & $\mathrm{F}$ & 3 & 4 & 6 & 13 & 14 & 3.77 \\
& $\%$ & $7.5 \%$ & $10.0 \%$ & $15.0 \%$ & $32.5 \%$ & $35.0 \%$ & \\
\hline
\end{tabular}

It is evident from the results about human rights implementation that $61.6 \%$ students were in agreement while $24.9 \%$ students were in disagreement. The mean 3.51 demonstrated that the statement was supported by the students. Teachers' results depicted that $67.5 \%$ teachers were in agreement while $25.0 \%$ teachers were in disagreement. The mean 3.77 demonstrated that the statement was supported by the teachers.

Table 4. Perceptions of students and teachers about freedom of thoughts

$\begin{array}{lllllll}\text { Students } & \text { F } & 41 & 53 & 59 & 151 & 93\end{array}$

$\begin{array}{llllllll}\text { Students } & \% & 10.3 \% & 13.3 \% & 14.8 \% & 37.9 \% & 23.4 \% & 3.53\end{array}$

$\begin{array}{lllllll}\text { Teachers } & \mathrm{F} & 3 & 5 & 7 & 10 & 15 \\ & \% & 7.5 \% & 12.5 \% & 17.5 \% & 25.0 \% & 37.5 \%\end{array}$

Result regarding encouragement of freedom of thoughts provided in the table proved that $61.3 \%$ students had the same opinion and $28.1 \%$ students differed with it. The mean 3.53 proved that majority of the students were in favor of it. Responses given about teachers proved that $62.5 \%$ teachers had the same opinion and $30.0 \%$ teachers differed with it. The mean 3.72 proved that mostly teachers were in favor of it.

Table 5 Perceptions of Students and teachers on importance of peace in the society

\begin{tabular}{llllllll}
\hline \multirow{2}{*}{ Students } & $\mathrm{F}$ & 46 & 46 & 50 & 168 & 88 & \multirow{2}{*}{3.52} \\
& $\%$ & $11.6 \%$ & $11.6 \%$ & $12.6 \%$ & $42.2 \%$ & $22.1 \%$ & \\
\multirow{5}{*}{ Teachers } & $\mathrm{F}$ & 0 & 2 & 6 & 23 & 9 & 3.97 \\
& $\%$ & $.0 \%$ & $5.0 \%$ & $15.0 \%$ & $57.5 \%$ & $22.5 \%$ & 3.9 \\
\hline
\end{tabular}

Results depicted in the table concerning the importance of peace in the society highlighted that $64.3 \%$ students were incompliance while $24.2 \%$ students were in noncompliance. The mean 3.52 demonstrated that the statement was supported by the students. Perceptions of the teachers proved that $80.0 \%$ teachers had the same opinion and $20.0 \%$ teachers 
differed with it. The mean 3.97 proved that mostly teachers were in favor of it.

Table 6 Perceptions of students and teachers regarding religious tolerance

\begin{tabular}{llllllll}
\hline \multirow{2}{*}{ Students } & $\mathrm{F}$ & 44 & 38 & 65 & 149 & 102 & \multirow{2}{*}{ (11.53 } \\
& $\%$ & $11.1 \%$ & $9.5 \%$ & $16.3 \%$ & $37.4 \%$ & $25.6 \%$ & \\
Teachers & $\mathrm{F}$ & 2 & 2 & 9 & 18 & 9 & 3.75 \\
& $\%$ & $5.0 \%$ & $5.0 \%$ & $22.5 \%$ & $45.0 \%$ & $22.5 \%$ & 3 \\
\hline
\end{tabular}

Results presented in the table about the creation of tolerance among different religions practiced in Pakistan, showed that $63 \%$ students were incompliance while $25.8 \%$ students were in noncompliance. The mean 3.53 demonstrated that the statement was supported by the students. Results about the teachers proved that $67.5 \%$ teachers had the same opinion and $27.5 \%$ teachers differed with it. The mean 3.75 proved that mostly teachers were in favor of it.

Table 7 Perceptions of students and teachers on national development

\begin{tabular}{llllllll}
\hline \multirow{2}{*}{ Students } & $\mathrm{F}$ & 40 & 53 & 55 & 151 & 99 & \multirow{2}{*}{ (15.53 } \\
& $\%$ & $10.1 \%$ & $13.3 \%$ & $13.8 \%$ & $37.9 \%$ & $24.9 \%$ & \\
\multirow{2}{*}{ Teachers } & $\mathrm{F}$ & 4 & 5 & 2 & 22 & 7 & 3.57 \\
& $\%$ & $10.0 \%$ & $12.5 \%$ & $5.0 \%$ & $55.0 \%$ & $17.5 \%$ & 3 \\
\hline
\end{tabular}

The table provided information about the perceptions of students and teachers regarding opportunities for national development. Results proved that $62.8 \%$ students had the same opinion and $27.1 \%$ students differed with it. The mean 3.53 proved that majority of the students were in favor of it. Results of teachers' perceptions depicted that $72.5 \%$ teachers were incompliance while $17.5 \%$ teachers were in noncompliance. The mean 3.57 demonstrated that the statement was supported by the teachers. Table 8 Perceptions of students and teachers about national heroes

\begin{tabular}{llllllll}
\hline \multirow{2}{*}{ Students } & $\mathrm{F}$ & 24 & 131 & 160 & 65 & 18 & \multirow{2}{*}{ (2.80 } \\
& $\%$ & $6.0 \%$ & $32.9 \%$ & $40.2 \%$ & $16.3 \%$ & $4.5 \%$ & \\
\multirow{2}{*}{ Teachers } & $\mathrm{F}$ & 0 & 3 & 4 & 25 & 8 & 3.95 \\
& $\%$ & $.0 \%$ & $7.5 \%$ & $10.0 \%$ & $62.5 \%$ & $20.0 \%$ & 3 \\
\hline
\end{tabular}

Results regarding the contributions of our national heroes, table proved that $20.8 \%$ students were in agreement while $73.1 \%$ students were in disagreement. The mean 2.80 demonstrated that most of the students were not in favor of it. Perceptions of teachers proved that $82.5 \%$ teachers had 
the same opinion and $17.5 \%$ teachers differed with it. The mean 3.95 proved that mostly teachers were in favor of it.

Table 9 Perceptions regarding promotion of dutifulness and sense of responsibility

\begin{tabular}{llllllll}
\hline \multirow{2}{*}{ Students } & $\mathrm{F}$ & 41 & 102 & 167 & 64 & 24 & \multirow{2}{*}{2.81} \\
& $\%$ & $10.3 \%$ & $25.6 \%$ & $42.0 \%$ & $16.1 \%$ & $6.0 \%$ & \\
\multirow{2}{*}{ Teachers } & $\mathrm{F}$ & 0 & 5 & 5 & 15 & 15 & 4.00 \\
& $\%$ & $.0 \%$ & $12.5 \%$ & $12.5 \%$ & $37.5 \%$ & $37.5 \%$ & 4.00 \\
\hline
\end{tabular}

Results provided in the table about dutifulness and sense of responsibility illustrated that $22.1 \%$ of the students approved the statement while $67.6 \%$ students disapproved it. The mean 2.81 depicted that best part of students disapproved it. Result given about teachers illustrated that $75.0 \%$ were incompliance while $25.0 \%$ were in noncompliance. The mean 4.00 demonstrated that the statement was supported by the teachers.

\section{Findings}

On the basis of data analysis by using percentage and mean as statistical tools the following findings were made.

\section{Students' Perceptions on Patriotism}

Pakistan Studies Textbooks at secondary level:

1. Promotes patriotism as the results showed the agreement of $73.1 \%$ students while disagreement of $19.1 \%$ of the students. The mean 3.78 proved that most of students were in favor of the statement.

2. Encourages democratic values by results depiction that $65.8 \%$ students were incompliance while $19.8 \%$ students were in noncompliance. The mean 3.56 demonstrated that the statement was supported by the students.

3. Promotes the implementation of human rights as the results showed that $61.6 \%$ students were incompliance while $24.9 \%$ students were in noncompliance. The mean 3.51 demonstrated that the statement was supported by the students.

4. Promotes freedom of thoughts for the results proved that $61.3 \%$ students had the same opinion and $28.1 \%$ students differed with it. The mean 3.53 proved that majority of the students were in favor of it.

5. Highlights the importance of peace in the society as the results depicted that $64.3 \%$ students were incompliance while $24.2 \%$ students were in 
noncompliance. The mean 3.52 demonstrated that the statement was supported by the students.

6. Creates tolerance among different religions practiced in Pakistan as evident by the results that $63 \%$ students were incompliance while $25.8 \%$ students were in noncompliance. The mean 3.53 confirmed that the statement was supported by the students.

7. Gives information about the opportunities for national development as shown by the, results that $62.8 \%$ students had the same opinion and $27.1 \%$ students differed with it. The mean 3.53 proved that majority of the students were in favor of it.

8. Do not favor the contributions of our national heroes as shown by the results that $20.8 \%$ students were in agreement while $73.1 \%$ students were in disagreement. The mean 2.80 demonstrated that most of the students were not in favor of it.

9. Do not promote dutifulness and sense of responsibility which results in illustration showed that $22.1 \%$ of the students approved the statement while $67.6 \%$ students disapproved it. The mean 2.81 depicted that best part of students disapproved it.

\section{Teachers' Perceptions on Patriotism}

The content of Pakistan Studies Textbooks at secondary level:

1. Promotes patriotism as the results proved that $62.5 \%$ teachers had the same opinion and $20.0 \%$ teachers differed with it. The mean 3.47 proved that mostly teachers were in favor of it.

2. Encourages democratic values as results depicted that $67.5 \%$ teachers were incompliance while $15.0 \%$ teachers were in noncompliance. The mean 3.52 confirmed that the statement was supported by the teachers.

3. Promotes the implementation of human rights which was evident by the results that $67.5 \%$ teachers were incompliance while $25.0 \%$ teachers were in noncompliance. The mean 3.77 demonstrated that the statement was supported by the teachers.

4. Promotes freedom of thoughts as the results proved that $62.5 \%$ teachers had the same opinion and $30.0 \%$ teachers differed with it. The mean 3.72 proved that mostly teachers were in favor of it. 
5. Highlights the importance of peace in the society as the results showed that $80.0 \%$ teachers had the same opinion and $20.0 \%$ teachers differed with it. The mean 3.97 proved that mostly teachers were in favor of it.

6. Creates tolerance among different religions practiced in Pakistan as results proved that $67.5 \%$ teachers had the same opinion and $27.5 \%$ teachers differed with it. The mean 3.75 proved that mostly teachers were in favor of it.

7. Gives information about the opportunities for national development by the illustration of the results that $72.5 \%$ teachers were incompliance while $17.5 \%$ teachers were in noncompliance. The mean 3.57 demonstrated that the statement was supported by the teachers.

8. Highlights the contributions of our national heroes as results proved that $82.5 \%$ teachers had the same opinion and $17.5 \%$ teachers differed with it. The mean 3.95 proved that mostly teachers were in favor of it.

9. Promotes dutifulness and sense of responsibility as results depicted that $75.0 \%$ teachers were incompliance while $25.0 \%$ teachers were in noncompliance. The mean 4.00 demonstrated that the statement was supported by the teachers.

\section{Conclusions}

From the findings of present study regarding the patriotism following conclusions were drawn.

1. Both teachers and students were inclined that a content of Pakistan Studies Textbooks at secondary level promotes patriotism.

2. Majority of teachers and students agreed that a content of Pakistan Studies Textbooks at secondary level encourages democratic values.

3. Most of teachers and students approved that contents of Pakistan Studies Textbooks at secondary level promotes the implementation of human rights.

4. A large number of teachers and students were inclined that a content of Pakistan Studies Textbooks at secondary level promotes freedom of thoughts.

5. Mostly teachers and students agreed that a content of Pakistan Studies Textbooks at secondary level highlights the importance of peace in the society. 
6. A significant number of teachers and students agreed that a content of Pakistan Studies Textbooks at secondary level creates tolerance among different religions practiced in Pakistan.

7. Both teachers and students were of the opinion that a content of Pakistan Studies Textbooks at secondary level gives information about the opportunities for national development.

8. There were difference between the perceptions of the students and teachers that the content of Pakistan Studies Textbooks at secondary level highlights the contribution of national heroes. Majority of the students disagreed while most of the teachers were agreed with the statement.

9. Differences were found in perceptions of the students and teachers that the content of Pakistan Studies Textbooks at secondary level promotes dutifulness and sense of responsibility. A large number of students disagreed while most of the teachers agreed with the statement.

\section{Recommendations}

1. Students did not approve that content of Pakistan Studies Textbooks at secondary level highlights the contributions of our national heroes. Curriculum planners and textbook developers may include lessons to pay gratitude to our national heroes. Textbook for $10^{\text {th }}$ class may include topics about the distinguished people who contributed in the development of different walks of life.

2. Students were not of the opinion that the content of Pakistan Studies Textbooks at secondary level promotes dutifulness. Thus in order to promote dutifulness and sense of responsibilities among the students the National Curriculum for Pakistan Studies class IX \& X 2006 may address the issue and the contents of Pakistan Studies Textbooks at secondary level should include topics which promotes dutifulness and sense of responsibility.

\section{References}

Bloom, J. (2006). Selected concepts of curriculum. retrieved from www.jeff bloom.net/docs/selectedconceptsofcurriculum.pdf. 
Faizi, W. N. (2010). The reflection of Islamic values in the compulsory subjects of social sciences at secondary (IX-X) level in Karachi (Unpublished doctoral thesis), Jinnah University for Women, Karachi.

Hashmi, R. S. (2014). Ethnic politics: An issue to National integration (The case of Pakistan). A Research Journal of South Asian Studies, 29(1), 345-361.

Jupri, R. (1994). Malaysian teachers' evaluation of form one (KBSM) English textbooks: A comparative analysis (Master's thesis, University of Essex). Retrieved from etd.uum.edu.my/view/divisions/comm/1994.type.html

Khan, I. (2012). A critical analysis of Pakistan studies curriculum (Unpublished doctoral thesis), University of Peshawar.

Lawrence, W. P. W. (2011). Textbook evaluation: A framework for evaluating the fitness of the Hong Kong new secondary school (NSS) curriculum (Unpublished Master of Arts thesis), City University of Hong Kong.

Mahmood, K. (2010). Developing alternate criteria for the evaluation of textbooks (Unpublished doctoral thesis), Allama Iqbal Open University, Islamabad.

Ministry of Education (1959). Report of the Commission on National Education 1959. Islamabad, Pakistan: Author.

Ministry of Education. (1998). National Education Policy 1998-2010. Islamabad: Planning and Policy Wing.

Ministry of Education. (2006). National Curriculum for Pakistan Studies Grades $I X$ - $X$. Islamabad, Pakistan. 
Mukundan, J. (2007). Evaluation of English language textbooks: Some important issues for consideration. Journal of NELTA, 12(1\&2), 80-84.

Nathanson, S. (1989). In defense of moderate patriotism. Ethics. (99), 535552.

Primoratz, I. (2015). Patriotism. In E. N. Zalta (Ed.), The Stanford Encyclopedia of Philosophy. Retrieved from http://plato.stanford.edu/archives/spr2015 /entries/patriotism/

Print, M. (1993). Curriculum development and design. Australia: Alien \& Unwin.

Rashid, M. (2004). Allied material of curriculum development and instruction. M.Ed code 838 ( $7^{\text {th }}$ ed.). Islamabad: Allama Iqbal Open University.

Sarem, S. N., Hamidi, H., \& Mahmoudie, R. (2013). A critical look at textbook evaluation: A case study of evaluating an ESP course book: English for international tourism. International Research Journal for Applied and Basic Sciences, 4(2), 372-380. Retrieved from www.irjabs.com

Shahid, S. M. (2000). Curriculum development. Lahore: Majeed Book Depot.

Tomlinson, B. \& Masuhara, H. (2004). Developing Language Course Materials. Singapore: SEAMEO Regional Language Centre.

Valverde, G. A., Bianchi, L. J., Wolfe, R. G., Schmidt, W. H., \& Houang, R. T. (2002). According to the book, using TIMSS to investigate the translation of policy into practice through the world of textbooks. Docdrecht: Kluwer Academic Publishers. 